INDEPENDENT JOURNAL OF MANAGEMENT \& PRODUCTION (IJM\&P)

http://www.ijmp.jor.br

v. 5 , n. 4, October - December 2014

ISSN: 2236-269X

DOI: 10.14807/ijmp.v5i4.238

\title{
ALIGNMENT OF BALANCED SCORECARD PERSPECTIVES WITH SUPPLY CHAIN MANAGEMENT OBJECTIVES: A LITERATURE REVIEW
}

Thales Botelho de Sousa Engineering School of São Carlos, University of São Paulo, Brazil E-mail: thalesbotelho@sc.usp.br

Carlos Eduardo Soares Camparotti Engineering School of São Carlos, University of São Paulo, Brazil E-mail: carloscamparotti@sc.usp.br

Kleber Francisco Esposto Engineering School of São Carlos, University of São Paulo, Brazil E-mail:kleber@sc.usp.br

Fábio Müller Guerrini Engineering School of São Carlos, University of São Paulo, Brazil E-mail: guerrini@sc.usp.br

\section{ABSTRACT}

Having in view the fast diffusion of the Balanced Scorecard since its development in the 1990s, as well as your application in various industrial sectors, this paper aims to present a literature review on the alignment of this performance measurement system with the Supply Chain Management. This research was motivated by the finding of an increase in the annual number of papers published over the years. Through a literature review 43 papers related to the theme were localized in databases SCIELO, SCOPUS and Web of Science. Key metrics, methodological procedures most used for developing the papers localized, benefits and limitations of using the system, as well as research gaps indicated for future works are presented. The main contribution of this research focuses on condense into a single 
DOI: 10.14807/ijmp.v5i4.238

material an overview of the assessment methods of Supply Chain Management based on the Balanced Scorecard perspectives. Several metrics have been proposed for the development of this performance measurement system, encompassing other perspectives beyond the four traditional Balanced Scorecard perspectives.

Keywords: Balanced Scorecard. Supply Chain Management. Literature Review, Performance Measurement System.

\section{INTRODUCTION}

Performance management of supply chains has become an activity of recognized importance, especially due to complex nature of business processes, usually involving multiple decision criteria. The reason for this is clear: organizations are looking for ways to improve their operational performance through better integration of operations across the value chain. According to Singhal and Singhal (2012), the area of Operations Management (OM) and Supply Chain (SC) currently has an excessive offer of models and a lack of theories.

The Supply Chain Management (SCM) impacts not only overall organizational performance, but also competitive advantage of organizations (LI et al., 2006). In SCM, performance assessment aims to obtain information on activities that are not appropriate to the established goals in order to redirect its course and also to identify opportunities for improvement. Both when performance is below the target and requires immediate action to not impact the financial results, as when performance is repeatedly upper and determines new goal, the performance assessment is required and must be addressed and managed in a systematic way in an organization. The main benefit of a performance management system for SCs is to provide a comprehensive and current framework of information on the performance of a business. Another contribution is to enable a diagnosis of the weaknesses of the business and decide when and where corrective actions become necessary in order to assess the impact of these actions on the performance of all (KUENG; WETTSTEIN; LIST, 2001).

The Balanced Scorecard (BSC) is a vehicle that reflects the mission and strategy of an organization into a set of objective and quantifiable measures 
DOI: 10.14807/ijmp.v5i4.238

organized into four different perspectives: financial, customer, internal processes and learning and growth (KAPLAN; NORTON, 1996; TSANG; JARDINE; KOLODNY, 1999). According to several authors the four BSC perspectives are appropriate for overcoming the problems related to performance assessment in SCs. Researches exploring the application of the BSC as a performance measurement system for performance management of SCs are cited in several studies, such as those of Brewer and Speh (2000, 2001), Kleijnen and Smits (2003), Park, Lee and Yoo (2005), among others.

This paper aims to present a brief literature review on the alignment of the BSC with the SCM. The literature survey was conducted in journals indexed in the databases SCIELO, SCOPUS and Web of Science, involving specific objectives that allow a critical analysis of data collected and exposition of the main results.

This paper aims to answer the following questions:

1) What are the main metrics developed based on the BSC for assessing the performance of SCs?

2) What research procedures most commonly used for the development of papers?

3) What are the main limitations for application of this performance measurement system?

\section{METHODOLOGICAL PROCEDURES USED FOR DEVELOPING THE RESEARCH}

This study makes an exploratory research in order to identify characteristics of the papers on alignment of BSC with SCM and demonstrate the methods and metrics recently developed in the literature. According to Forza (2002), the purpose of exploratory research is to build an initial idea about a topic, providing the basis for more detailed studies, in order to improve the techniques currently available. Regarding the technical procedures used to carry out this paper, it was conceived through bibliographical research. The bibliographical research allows the identification of state of the art and possible gaps that may exist, and identification of opportunities for new contributions to the topic under study (VILLAS; SOARES; RUSSO, 2008). 
DOI: 10.14807/ijmp.v5i4.238

In this review, only papers published in journals were analyzed, because they have more careful selection and assessment than papers published in conferences and symposiums (CARNEVALLI; MIGUEL, 2008), and are considered researches of highest level, both for gathering information, and for dissemination of new results and discoveries (NGAl et al., 2008).

For selecting the publications of interest, they were searched by title, abstract, keywords, irrespective of the period of publication, the following terms, combined: Balanced Scorecard and Supply Chain. Subsequently proceeded to the reading and analysis of abstract and introduction of the papers found, by selecting those with relevance to the research objectives. With refinements, 43 papers on the theme were obtained in the three bibliographical databases. Importantly, the papers obtained in 2014 include only the publications produced until the month of April. Relevant papers found in the references bus that were not inserted into the databases were added in the literature review, in order to make it more comprehensive.

\section{RESULTS OF THE LITERATURE REVIEW}

\subsection{Use of the Balanced Scorecard for assessing supply chains performance}

According to Zimmermann and Seuring (2009), the BSC has gained increasing acceptance as an instrument for the implementation of business strategies, and transforms them into related performance measures, which can be extended to the performance assessment of SCs. Brewer and Speh (2001) and Bhattacharya et al. (2014) cite the following reasons for using the BSC in this assessment:

1) The goals of SCM (reduction of service time, response flexibility, reduced unit cost, launching new products) can be measured through internal process perspective.

2) The results of SCM - both as they related to customers (quality, time, flexibility and value), as those achieved financial aspects (profit margin, cash flow, income growth and return on assets) - can be measured through financial and customers perspectives.

3) The rate of improvement in SCM (innovation of products and processes, company management, information flow, identification of threats and substitutes) can be measured by learning and growth perspective. 
DOI: 10.14807/ijmp.v5i4.238

4) It can to be used as an information system.

5) It enables to visualize the cause and effect relationships among different measures.

The BSC is capable of combining objectives, quantitative data, and subjective judgments, and includes the long-term trend monitoring and forecasting facilities required to support strategic planning (CHANG et al., 2013). According to Kleijnen and Smits (2003), the performance problem becomes simpler when the BSC metrics are shared by all stakeholders (managers, employees, customers, suppliers, banks, etc.), all business units within a company's division, all divisions within a company, and all companies in the SC.

Reefke and Trocchi (2013) claim that the formulation of a BSC for SCM is divided into six steps: definition of the SCM strategy, definition of the scope of application, identification of environmental and social exposure, determination of strategic relevance of sustainability aspects, definition of the cause-effect relationships, definition of measures and indicators. For Bhagwat and Sharma (2007a) this process involves the creation of awareness for the concept of BSC to organization SCM, collect and analyze of information on corporate, business and SCM strategy as well as potential metrics related to the four perspectives, clear definition of specific business objectives and goals, development of a preliminary performance measurement system, reception of company management comments and feedback, consensus on the system that will be used by the organization, and presentation of system for all stakeholders.

The prioritization of different perspectives for a company is an issue which needs to be addressed (BHAGWAT; SHARMA, 2007b). According to Verdecho, Alfaro and Rodriguez-Rodriguez (2009), alignment of SC BCS and performance measurement system of the individual companies should include other collaborative elements measurement such as equity, trust and commitment in the SC, as well as levels of collaboration within the processes (strategic, tactical and operational). Already for Park, Lee and Yoo (2005) to take SCM into account, the notion of the BSC needs to expand the internal business process perspective to include the interorganizational process for the communication and collaboration of SCM between 
DOI: 10.14807/ijmp.v5i4.238

suppliers and customers, and the customer perspective should to consider the demand chain process.

For Alfaro et al. (2009), the BSC fills five characteristics requirements that performance measurement systems that deal with business process interoperability: business process measurement, performance measurement system intra and interorganizational levels measurement, intra-inter-process connection measurement, inter-organizational coordination measurement, and common inter-organizational strategy.

In order to put the BSC for working, companies should articulate goals for time, quality, performance and service and then translate these goals into specific measures (BHAGWAT; SHARMA, 2007a). According to Chang (2009), the BSC has been utilized for assessing SCM performance in the dimensions customer integration, internal process integration, supplier services and material integration, technology and planning integration, measurement integration, and relationship integration. By combining these different perspectives, BSC helps managers to understand the inter-relationships and tradeoffs between alternative performance dimensions, thus leading to improved decision making and problem solving (RAJESH et al. 2012). In the SC, upstream companies attach more importance to customer integration, and downstream companies attach more importance to supplier integration (CHANG et al., 2013).

According to Rajesh et al. (2012), the BSC it is still out of reach for most of the small and medium-sized organizations, because its development requires a lot of skill and expertise of the management, time and expenditure of money. For Barber (2008), criticisms of the BSC and its many applications and various developments state that people and suppliers are excluded, regulations and competitive environments are ignored as well as the environmental and social aspects of industry. According to Reefke and Trocchi (2013), environmental and social aspects can be integrated in the four perspectives by establishing strategic priorities that influence the formulation of targets, measures, and respective indicators, representing strategically important factors which may otherwise not be sufficiently represented through integration into the four standard BSC perspectives. 
DOI: 10.14807/ijmp.v5i4.238

\subsection{Identified limitations in literature for the performance measurement system}

Naini, Aliahmadi and Jafari-Eskandari (2011) claim that there are some limitations to the BSC for SCM such as does not take into account the relation of cause and effect over time, does not provide mechanisms for selecting best measures of performance, does not define value chains in strategic operations, and is not dynamic enough for online control.

The literature review of Agami, Saleh and Rasmy (2012) reveals that most of the already existing SCs performance measurement systems are inflexible and lack continual improvement. In an attempt to bridge this gap, the authors propose a dynamic, continuous and hybrid system framework that integrates systems thinking, strategic planning, BSCs, SCOR model, Theory Of Constraints Thinking Processes (TOCTP), optimization and eigen structure analysis into a cohesive approach for improving SC performance. For Thakkar, Kanda and Deshmukh (2009) the integration between SCOR and BSC ensures the greater effectiveness of performance measurement system, because the BSC does not provide a mechanism for maintaining the relevance of defined measures, fails to integrate top level, strategic scorecard, and operational level measures potentially making execution of strategy problematic, and fails to specify a user-centered development process. The SCOR model overcomes these shortcomings by adopting a building block approach and offers complete traceability, by defining the type of process (planning, execution and enabling) and configuring them to suit the SC requirements, and generating sufficient information to even develop tailor-made software system.

According to Xian, Qiu and Zhang (2013), although the performance measurement of SCM can be studied as a BSC, such approach is not effective for corporate-level assessment in that many measures can also be influenced by other business activities. For Xian, Qiu and Zhang (2013), the index of SC performance assessment with BSC in existing literature is not fully measurable and the SCM measures are used only for constructing the theoretical framework of SC performance assessment index system, but the assessment model or algorithm is scarce. Based in this, Xian, Qiu and Zhang (2013) propose a Fuzzy Hierarchy Evaluation Model (FHEM) with the Balanced Supply Chain Scorecard (BSCS) based 
DOI: 10.14807/ijmp.v5i4.238

on the Fuzzy Principal Component Analysis (FPCA), that overcomes the multicollinearity in the index system of BSC and yields better performance assessment accuracy than the other methods.

Discussion of the complex issues of a balanced system of performance assessment is not simple. BSC performance is subjective, cause-effect relationships are not clear, and it is necessary to assign non-equal priorities to perspectives and performance indicators within each perspective (DE FELICE; PETRILLO, 2013). For De Felice and Petrillo (2013) and Bhagwat and Sharma (2009), Analytic Hierarchy Process (AHP) represents one of the methods that can address the complex issues of a balanced system of performance assessment. The application of this method along with BSC considers several relevant dimensions of organizational performance and formally explains how to weight their importance within a comprehensive framework.

\subsection{Technical procedures used for the development of papers and industrial sectors analyzed}

Table 1 shows the classification and annual distribution of papers according to the technical procedure used for the development, according to the classification used in the area of operations management. Although the literature review to be an essential part of the development of any academic paper (LAKATOS; MARCONI, 2007), in classification used in this paper were considered of theoretical nature the papers that used only the conceptual approach in its design.

Table 1: Classification and annual distribution of papers according to the technical procedure used for its development

\begin{tabular}{|c|c|c|c|c|c|c|c|c|c|c|c|c|c|}
\hline \multirow[b]{2}{*}{ Technical procedure } & \multicolumn{13}{|c|}{ Year } \\
\hline & 옹 & ֻ̊ & ষ্ণ & 옹 & $\begin{array}{l}\text { ̊ } \\
\text { ㅇ }\end{array}$ & 옹 & $\begin{array}{l}\infty \\
\text { ᄋ }\end{array}$ & 옹 & $\frac{0}{\grave{0}}$ & 홍 & $\frac{N}{\stackrel{N}{N}}$ & $\stackrel{m}{\grave{N}}$ & $\frac{\text { ர }}{\text { ¿ }}$ \\
\hline Case study & & 1 & 1 & 2 & & 2 & & 4 & 1 & 2 & 5 & 3 & 1 \\
\hline Literature Review & 1 & & & & & & 1 & 2 & 2 & 1 & & 2 & \\
\hline Modeling & & & & & & & & & & & & 2 & \\
\hline Simulation & & 1 & & & & & & & & 1 & & 1 & \\
\hline Survey & & & & & 1 & 1 & 1 & 2 & & & 2 & & \\
\hline
\end{tabular}


According to the data in Table 1 it can be seen that of the technical procedures used, the case study showed a higher incidence (OLSMATS; DOMINIC, 2003; LOHMAN; FORTUIN; WOUTERS, 2004; KUMAR; OZDAMA; NG, 2005; PARK; LEE; YOO, 2005; BHAGWAT; SHARMA, 2007a; SHARMA; BHAGWAT, 2007; CHANG, 2009; THAKKAR; KANDA; DESHMUKH, 2009; YANG, 2009; ZIMMERMANN; SEURING, 2009; BIGLIARDI; BOTTANI, 2010; NAINI; ALIAHMADI; JAFARI-ESKANDARI, 2011; WANG; LI, 2011; ADARME-JAIMES; ARANGOSERNA; COGOLLO-FLÓREZ, 2012; AGAMI; SALEH; RASMY, 2012; FRANCESCHINI; TURINA, 2012; NAJMI; MAKUI, 2012; RAJESH et al., 2012; CHANG et al., 2013; FAN et al., 2013; KALL et al., 2013; BHATTACHARYA et al., 2014). Then came the literature review (BULLINGER; KÜHNER; VAN HOOF, 2002; BARBER, 2008; ALFARO et al., 2009; VERDECHO; ALFARO; RODRIGUEZRODRIGUEZ, 2009; AKYUZ; ERKAN, 2010; SHAW; GRANT; MANGAN, 2010; CHILDERHOUSE; TOWILL, 2011; REEFKE; TROCCHI, 2013; HOLIMCHAYACHOTIKUL et al., 2014), survey (KNOTTS; JONES; UDELL, 2006; BHAGWAT; SHARMA, 2007b; VARMA; WADHWA; DESHMUKH, 2008; BHAGWAT; SHARMA, 2009; CHIA; GOH; HUM, 2009; KIM; RHEE, 2012; WU; CHANG, 2012), simulation (KLEIJNEN; SMITS, 2003; KHAJI; SHAFAEI, 2011; BARNABÈ et al., 2013) and modeling (DE FELICE; PETRILLO, 2013; XIAN; QIU; ZHANG, 2013). The high incidence of case studies is explained by maturation of thematic research over the years and need for thorough analysis of the application of the performance measurement system in organizational practices.

Table 1 shows that although with some fluctuations, there was growth in studies that address the alignment of the BSC with SCM over the years, considering that in 2002 only 1 paper was published and there was a peak of 8 posts in 2009 and 2013. The use of quantitative techniques has been growing lately, due to the use of methods such as fuzzy logic, AHP, ANP, among others, used for reducing the subjectivity of the analysis and validating adjustments made in methodologies already established or new techniques developed.

The industrial sectors in which the methods were applied are diverse, encompassing industry of machinery (CHANG, 2009), electronics (SHARMA; 
DOI: 10.14807/ijmp.v5i4.238

BHAGWAT, 2007; CHANG, 2009; WU; CHANG, 2012), steel manufacturer (CHANG, 2009), water and sewage service companies (FRANCESCHINI; TURINA, 2012), automotive (SHARMA; BHAGWAT, 2007; ZIMMERMANN; SEURING, 2009; NAINI; ALIAHMADI; JAFARI-ESKANDARI, 2011; NAJMI; MAKUI, 2012), chemical (ZIMMERMANN; SEURING, 2009), food SC (OLSMATS; DOMINIC, 2003; PARK; LEE; YOO, 2005; SHARMA; BHAGWAT, 2007; BIGLIARDI; BOTTANI, 2010), mass merchandiser market (KNOTTS; JONES; UDELL, 2006), cosmetics and healthcare products (PARK; LEE; YOO, 2005), services (BHAGWAT; SHARMA, 2007b; BHAGWAT; SHARMA, 2009; CHANG et al., 2013), naval (ADARME-JAIMES; ARANGO-SERNA; COGOLLO-FLÓREZ, 2012), consumable goods SCs (SHARMA; BHAGWAT, 2007), hospitals (KUMAR; OZDAMAR; NG, 2005), carpet-manufacturing (BHATTACHARYA et al., 2014), leading logistics company (CHIA; GOH; HUM, 2009; XIAN; QIU; ZHANG, 2013), high tech engineering (BHAGWAT; SHARMA, 2007b; BHAGWAT; SHARMA, 2009), packaging and distribution (BHAGWAT; SHARMA, 2007b; BHAGWAT; SHARMA, 2009), fashion industry (DE FELICE; PETRILLO, 2013), beverage (SHARMA; BHAGWAT, 2007; KALL et al., 2013), petroleum SC (VARMA; WADHWA; DESHMUKH, 2008), third party logistics service provider (RAJESH et al., 2012), sportswear (LOHMAN; FORTUIN; WOUTERS, 2004), leading welding consumable manufacturer (BHAGWAT; SHARMA, 2007a), leading manufacturer of brakes and clutches (BHAGWAT; SHARMA, 2007a), iron handicraft manufacturing (BHAGWAT; SHARMA, 2007a), green SCM (KIM; RHEE, 2012), among others unidentified (THAKKAR; KANDA; DESHMUKH, 2009; YANG, 2009; KHAJI; SHAFAEI, 2011; WANG; LI, 2011; AGAMI; SALEH; RASMY, 2012; FAN et al., 2013).

\subsection{Metrics proposed in the literature for the performance measurement system development}

Chang (2009), Naini, Aliahmadi and Jafari-Eskandari (2011), and Chang et al. (2013) claim that the alignment of conceptual BSC frameworks with the SCM objectives ensures integration of different company operations, discussion of company relationships with it external business environment, consistent monitoring approaches for all organizational partners, companies connection with the general organizational strategies, employees engagement with operational objectives in measuring performance, check of only a few measures or performance indicators at 
DOI: 10.14807/ijmp.v5i4.238

any one time, bridge between financial and non-financial fields, and improved management of information in organizations. Furthermore, for De Felice and Petrillo (2013), using the BSC allows for stakeholders to determine the health of short-, medium- and long-term objectives at a glance.

Based on the literature review, several authors have proposed specific structures that align performance metrics of supply chains with the perspectives of the Balanced Scorecard. In this paper, in order to portray the layout of these structures, a model that portrays a combination of the most important features in some of these proposals is presented. The representation of this model can be seen in Table 2.

Table 2 - Alignment model of Balanced Scorecard perspectives with Supply Chain Management objectives

\begin{tabular}{|c|c|c|}
\hline Perspective & Objectives & Measurements \\
\hline \multirow{3}{*}{$\begin{array}{l}\text { Financial } \\
\text { Perspective }\end{array}$} & Cash flow & $\begin{array}{l}\text { - Cash flow increase (BREWER; SPEH, 2000; CHANG et al., 2013; } \\
\text { DE FELICE; PETRILLO, 2013; PARK; LEE; YOO, 2005; WANG; LI, } \\
\text { 2011) } \\
\text { - Cash flow payback period (FAN et al., 2013) } \\
\text { - Variations against budget (BIGLIARDI; BOTTANI, 2010; SHARMA; } \\
\text { BHAGWAT, 2007) }\end{array}$ \\
\hline & $\begin{array}{c}\text { Costs } \\
\text { structure }\end{array}$ & $\begin{array}{l}\text { - Improving operational efficiency and asset utilization (ADARME- } \\
\text { JAIMES; ARANGO-SERNA; COGOLLO-FLÓREZ; 2012; } \\
\text { BHATTACHARYA et al., 2014; BULLINGER; KÜHNER; VAN } \\
\text { HOOF, 2002; FRANCESCHINI; TURINA, 2012; WU; CHANG, } \\
\text { 2012) } \\
\text { - Operational flexibility (NAJMI; MAKUI, 2012) } \\
\text { - Raw material prices (VARMA; WADHWA; DESHMUKH, 2008) }\end{array}$ \\
\hline & Profitability & $\begin{array}{l}\text { - Energy efficiency saving (BHATTACHARYA et al., 2014; REEFKE; } \\
\text { TROCCHI, 2013; SHAW; GRANT; MANGAN, 2010) } \\
\text { - Profit by employee (CHANG et al., 2013) } \\
\text { - Profit margins increase (BARNABÈ et al., 2013; BREWER; SPEH, } \\
\text { 2000; DE FELICE; PETRILLO, 2013; FAN et al., 2013; KLEIJNEN; } \\
\text { SMITS, 2003; PARK; LEE; YOO, 2005; RAJESH et al., 2012; } \\
\text { REEFKE; TROCCHI, 2013) } \\
\text { - Return on assets increase (XIAN; QIU; ZHANG, 2013; WU; } \\
\text { CHANG, 2012) } \\
\text { - Returns on investments increase (BHAGWAT; SHARMA, 2007a; } \\
\text { BIGLIARDI; BOTTANI, 2010; DE FELICE; PETRILLO, 2013; XIAN; }\end{array}$ \\
\hline (i) & $\begin{array}{l}{[\text { http:/ }} \\
\text { Licens }\end{array}$ & $\begin{array}{l}\text { 1s.org/licenses/by/3.0/us/] } \\
\text { ive Commons Attribution } 3.0 \text { United States License }\end{array}$ \\
\hline
\end{tabular}


DOI: 10.14807/ijmp.v5i4.238

\begin{tabular}{|c|c|c|}
\hline & & QIU; ZHANG, 2013) \\
\hline & $\begin{array}{l}\text { Revenue } \\
\text { growth }\end{array}$ & $\begin{array}{l}\text { - Reduced costs per hour of operation and transport (BHAGWAT; } \\
\text { SHARMA, 2007a; NAINI; ALIAHMADI; JAFARI-ESKANDARI, 2011) } \\
\text { - Revenues from sales and market share increase (BULLINGER; } \\
\text { KÜHNER; VAN HOOF, 2002; CHANG et al., 2013; KLEIJNEN; } \\
\text { SMITS, 2003; VARMA; WADHWA; DESHMUKH, 2008; WANG; LI, } \\
\text { 2011; WU; CHANG, 2012; XIAN; QIU; ZHANG, 2013; } \\
\text { ZIMMERMANN; SEURING, 2009) }\end{array}$ \\
\hline & $\begin{array}{l}\text { Company } \\
\text { image }\end{array}$ & $\begin{array}{l}\text { - Business ethics (BHATTACHARYA et al., 2014) } \\
\text { - Environmental policy (SHAW; GRANT; MANGAN, 2010) } \\
\text { - Getting new customers (ADARME-JAIMES; ARANGO-SERNA; } \\
\text { COGOLLO-FLÓREZ, 2012) } \\
\text { - Increase of image and reputation of the company and the } \\
\text { recognition rate of the corporate market (BHATTACHARYA et al., } \\
\text { 2014; FRANCESCHINI; TURINA, 2012; PARK; LEE; YOO, 2005; } \\
\text { REEFKE; TROCCHI, 2013; XIAN; QIU; ZHANG, 2013; WU; } \\
\text { CHANG, 2012) } \\
\text { - ISO accreditation (SHAW; GRANT; MANGAN, 2010) }\end{array}$ \\
\hline $\begin{array}{l}\text { Customers } \\
\text { Perspective }\end{array}$ & $\begin{array}{l}\text { Customer } \\
\text { relationship }\end{array}$ & $\begin{array}{l}\text { - Assistance from the supplier in resolving technical problems (WU; } \\
\text { CHANG, 2012) } \\
\text { - Customer retention rate (ADARME-JAIMES; ARANGO-SERNA; } \\
\text { COGOLLO-FLÓREZ, 2012; BARNABE et al., 2013; DE FELICE; } \\
\text { PETRILLO, 2013; FAN et al., 2013; LOHMAN; FORTUIN; } \\
\text { WOUTERS, 2004; REEFKE; TROCCHI, 2013; XIAN; QIU; ZHANG, } \\
\text { 2013; WANG; LI, 2011; ZIMMERMANN; SEURING, 2009) } \\
\text { - Improving delivery timely (BIGLIARDI; BOTTANI, 2010; CHANG et } \\
\text { al., 2013; WANG; LI, 2011; WU; CHANG, 2012) } \\
\text { - Improving the attendance rate of customer orders (BHAGWAT; } \\
\text { SHARMA, 2007a; BIGLIARDI; BOTTANI, 2010; CHANG et al., } \\
\text { 2013; LOHMAN; FORTUIN; WOUTERS, 2004; NAJMI; MAKUI, } \\
\text { 2012) } \\
\text { - Reduced response time to customers (PARK; LEE; YOO, 2005; } \\
\text { WU; CHANG, 2012) } \\
\text { - Responsiveness to urgent deliveries (BHAGWAT; SHARMA, } \\
\text { 2007a; BIGLIARDI; BOTTANI, 2010) }\end{array}$ \\
\hline & $\begin{array}{l}\text { Product } \\
\text { leadership }\end{array}$ & $\begin{array}{l}\text { - Conformance to specification for 'built to order' products } \\
\text { (KLEIJNEN; SMITS, 2003) } \\
\text { - Fill rate for mass products (KLEIJNEN; SMITS, 2003) } \\
\text { - Improvement of product quality (BHAGWAT; SHARMA, 2007a; } \\
\text { BIGLIARDI; BOTTANI, 2010; BULLINGER; KÜHNER; VAN HOOF, }\end{array}$ \\
\hline (c) (†) & & $\begin{array}{l}\text { org/licenses/by/3.0./usi/] } \\
\text { e Commons Attribution } 3.0 \text { United States License }\end{array}$ \\
\hline
\end{tabular}


DOI: 10.14807/ijmp.v5i4.238

\begin{tabular}{|c|c|c|}
\hline & & $\begin{array}{l}\text { 2002) } \\
\text { - Increased level of perceived value of the product (BHAGWAT; } \\
\text { SHARMA, 2007a; BIGLIARDI; BOTTANI, 2010; PARK; LEE; YOO, } \\
\text { 2005; SHARMA; BHAGWAT, 2007) } \\
\text { - Providing products with affordable prices (PARK; LEE; YOO, } \\
\text { 2005) } \\
\text { - Providing wide range of products (SHARMA; BHAGWAT, 2007; } \\
\text { WU; CHANG, 2012) } \\
\text { - Purity of product (VARMA; WADHWA; DESHMUKH, 2008) } \\
\text { - Reduction in the rate of return of products (CHANG et al., 2013; } \\
\text { PARK, LEE; YOO, 2005; WU; CHANG, 2012) }\end{array}$ \\
\hline \multirow[b]{3}{*}{$\begin{array}{l}\text { Business } \\
\text { Internal } \\
\text { Processes } \\
\text { Perspective }\end{array}$} & Colaboration & $\begin{array}{l}\text { - Benchmarking (SHAW; GRANT; MANGAN, 2010) } \\
\text { - Human resources management (REEFKE; TROCCHI, 2013) } \\
\text { - Improved sharing of order information, inventory and sales } \\
\text { forecasts (BIGLIARDI; BOTTANI, 2010; PARK; LEE; YOO, 2005; } \\
\text { VARMA; WADHWA; DESHMUKH, 2008; WU; CHANG, 2012) }\end{array}$ \\
\hline & $\begin{array}{c}\text { Deliveries } \\
\text { management }\end{array}$ & $\begin{array}{l}\text { - Improving the efficiency of delivery and better use of transportation } \\
\text { tools (DE FELICE; PETRILLO, 2013; NAJMI; MAKUI, 2012; PARK; } \\
\text { LEE; YOO, 2005; VARMA; WADHWA; DESHMUKH, 2008; WU; } \\
\text { CHANG, 2012; ZIMMERMANN; SEURING, 2009) }\end{array}$ \\
\hline & $\begin{array}{c}\text { Industrial } \\
\text { management }\end{array}$ & $\begin{array}{l}\text { - Carbon emissions ratio (SHAW; GRANT; MANGAN, 2010) } \\
\text { - Efficiency of energy use (BHATTACHARYA et al., 2014; } \\
\text { FRANCESCHINI; TURINA, 2012) } \\
\text { - Improving quality of production and inventory accuracy (BARNABE } \\
\text { et al., 2013; BIGLIARDI; BOTTANI, 2010; DE FELICE; PETRILLO, } \\
\text { 2013; XIAN; QIU; ZHANG, 2013; WU; CHANG, 2012; } \\
\text { ZIMMERMANN; SEURING, 2009) } \\
\text { - Increased production efficiency (BHATTACHARYA et al., 2014; } \\
\text { BIGLIARDI; BOTTANI, 2010; BULLINGER; KÜHNER; VAN HOOF, } \\
\text { 2002; CHANG et al., 2013; REEFKE; TROCCHI, 2013; WU; } \\
\text { CHANG, 2012) } \\
\text { - Process automation (CHANG et al., 2013) } \\
\text { - Production planning accuracy (FAN et al., 2013; XIAN; QIU; } \\
\text { ZHANG, 2013) } \\
\text { - Resource utilization (KLEIJNEN; SMITS, 2003; REEFKE; } \\
\text { TROCCHI, 2013) } \\
\text { - Rotation of inventories (ADARME-JAIMES; ARANGO-SERNA; } \\
\text { COGOLLO-FLÓREZ, 2012) }\end{array}$ \\
\hline
\end{tabular}


DOI: 10.14807/ijmp.v5i4.238

\begin{tabular}{|c|c|c|}
\hline & & $\begin{array}{l}\text { - Throughput (KLEIJNEN; SMITS, 2003) } \\
\text { - Time reduction of product development cycle, purchase orders and } \\
\text { process planning (BHAGWAT; SHARMA, 2007a; BIGLIARDI; } \\
\text { BOTTANI, 2010; SHARMA; BHAGWAT, 2007) }\end{array}$ \\
\hline & $\begin{array}{l}\text { Innovation } \\
\text { management }\end{array}$ & $\begin{array}{l}\text { - Identification of more innovative markets (BHAGWAT; SHARMA, } \\
\text { 2007a) } \\
\text { - New IT investments for SCM (KLEIJNEN; SMITS, 2003) } \\
\text { - Rapid commercialization of innovative products (XIAN; QIU; } \\
\text { ZHANG, 2013; WU; CHANG, 2012) }\end{array}$ \\
\hline & $\begin{array}{l}\text { Purchase } \\
\text { orders } \\
\text { processing }\end{array}$ & $\begin{array}{l}\text { - Improved fill rate of purchase orders and the percentage of } \\
\text { purchase orders online (CHANG et al., 2013; XIAN; QIU; ZHANG, } \\
\text { 2013; WU; CHANG, 2012) } \\
\text { - Reducing waste packaging at the customer-supplier interface } \\
\text { (NAINI; ALIAHMADI; JAFARI-ESKANDARI, 2011) }\end{array}$ \\
\hline & $\begin{array}{l}\text { Source } \\
\text { leadership }\end{array}$ & $\begin{array}{l}\text { - Greater accuracy in sales forecasting techniques (BHAGWAT; } \\
\text { SHARMA, 2007a; PARK; LEE; YOO, 2005; SHARMA; BHAGWAT, } \\
\text { 2007) } \\
\text { - Improving the quality of goods purchased and the delivery of } \\
\text { supplies online (WU; CHANG, 2012) } \\
\text { - Reduction in the price of goods purchased (WU; CHANG, 2012) }\end{array}$ \\
\hline \multirow{3}{*}{$\begin{array}{l}\text { Business } \\
\text { External } \\
\text { Processes } \\
\text { Perspective }\end{array}$} & $\begin{array}{c}\text { Improve } \\
\text { collaboration } \\
\text { with partners }\end{array}$ & $\begin{array}{l}\text { - Evaluating the environmental performance of suppliers (NAINI; } \\
\text { ALIAHMADI; JAFARI-ESKANDARI, 2011) } \\
\text { - Order, forecast and inventory information sharing (PARK; LEE; } \\
\text { YOO, 2005) } \\
\text { - Target cost ratio of synchronized supply chain (WANG; LI, 2011) } \\
\text { - Trust with partners (PARK; LEE; YOO, 2005) }\end{array}$ \\
\hline & $\begin{array}{l}\text { Improve } \\
\text { purchase } \\
\text { order } \\
\text { transaction } \\
\text { efficiency }\end{array}$ & $\begin{array}{l}\text { - Percentage of online purchase order processing (PARK; LEE; } \\
\text { YOO, 2005) } \\
\text { - Purchase order fill rate (PARK; LEE; YOO, 2005) }\end{array}$ \\
\hline & $\begin{array}{l}\text { Improve } \\
\text { source } \\
\text { leadership }\end{array}$ & $\begin{array}{l}\text { - Materials return rate (PARK; LEE; YOO, 2005) } \\
\text { - Quality and price of purchase goods (PARK; LEE; YOO, 2005) } \\
\text { - Supplier on-time delivery (PARK; LEE; YOO, 2005) } \\
\text { - Time and percentage of successful bids (PARK; LEE; YOO, 2005) }\end{array}$ \\
\hline $\begin{array}{l}\text { Learning and } \\
\text { Growth }\end{array}$ & Human capital & $\begin{array}{l}\text { - Improve the employee satisfaction (ADARME-JAIMES; ARANGO- } \\
\text { SERNA; COGOLLO-FLÓREZ, 2012; BARNABĖ et al., 2013; }\end{array}$ \\
\hline
\end{tabular}


DOI: 10.14807/ijmp.v5i4.238

\begin{tabular}{|c|c|c|}
\hline \multirow[t]{3}{*}{ Perspective } & & $\begin{array}{l}\text { BHATTACHARYA et al., 2014; CHANG et al., 2013; DE FELICE; } \\
\text { PETRILLO, 2013; LOHMAN; FORTUIN; WOUTERS, 2004; } \\
\text { REEFKE; TROCCHI, 2013) } \\
\text { - Improve the skills and capabilities of staff expertise (CHANG et al., } \\
\text { 2013; DE FELICE; PETRILLO, 2013; FRANCESCHINI; TURINA, } \\
\text { 2012; NAJMI; MAKUI, 2012; RAJESH et al., 2012; XIAN; QIU; } \\
\text { ZHANG, 2013; WU; CHANG, 2012) } \\
\text { - Middle management commitment (BHATTACHARYA et al., 2014) } \\
\text { - Professional development opportunities (LOHMAN; FORTUIN; } \\
\text { WOUTERS, 2004) } \\
\text { - Safer working conditions (REEFKE; TROCCHI, 2013) } \\
\text { - Top management commitment (BHATTACHARYA et al., 2014) }\end{array}$ \\
\hline & $\begin{array}{l}\text { Information } \\
\text { capital }\end{array}$ & $\begin{array}{l}\text { - Improvement of knowledge management and access to various } \\
\text { information (BARNABE et al., 2013; FAN et al., 2013; WU; CHANG, } \\
\text { 2012) } \\
\text { - Knowledge sharing degree (BIGLIARDI; BOTTANI, 2010; WANG; } \\
\text { LI, 2011; XIAN; QIU; ZHANG, 2013) } \\
\text { - Use of IT (VARMA; WADHWA; DESHMUKH, 2008) }\end{array}$ \\
\hline & $\begin{array}{c}\text { Organizational } \\
\text { capital }\end{array}$ & $\begin{array}{l}\text { - Adopt quality certification (FRANCESCHINI; TURINA, 2012) } \\
\text { - Assistance in solving technical problems (BIGLIARDI; BOTTANI, } \\
\text { 2010; SHARMA; BHAGWAT, 2007) } \\
\text { - Better working conditions (REEFKE; TROCCHI, 2013) } \\
\text { - Cleaner supply chain (SHAW; GRANT; MANGAN, 2010) } \\
\text { - Improved administrative processes (ZIMMERMANN; SEURING, } \\
\text { 2009) } \\
\text { - Improving the sharing of knowledge and awareness of staff's } \\
\text { vision, objectives and goals of the organization (CHANG et al., } \\
\text { 2013; WU; CHANG, 2012) } \\
\text { - Increase R\&D activities (BULLINGER; KÜHNER; VAN HOOF, } \\
\text { 2002; DE FELICE; PETRILLO, 2013; FRANCESCHINI; TURINA, } \\
\text { 2012) } \\
\text { - Maintaining the agility and flexibility to adapt to changing business } \\
\text { conditions (NAINI; ALIAHMADI; JAFARI-ESKANDARI, 2011) } \\
\text { - SCM improvement procedures (CHANG et al., 2013) }\end{array}$ \\
\hline
\end{tabular}

\section{CONCLUSIONS}


DOI: 10.14807/ijmp.v5i4.238

The performance measurement is an essential element of effective planning and control as well as decision-making. The measurement results show the effects of the strategies and potential opportunities in the SCM.

This paper presented a literature review on the BSC alignment with the SCM, seeking to characterize the state of the art on the theme, presenting a set of specific metrics for each perspective in the major papers, some reasons for using measurement system for such assessments, as well as the advantages of use. Based on several papers, the use of BSC for measuring SC performance is useful not only for firms and managers but also provides clear direction to researchers for accurate measurement of each performance.

The fact that the case study to be the technical procedure most used in researches corroborates the studies of Berto and Nakano (2000), Miguel (2007) and Walter and Tubino (2013), which point the case study as the methodological approach most commonly used in the area of industrial engineering and OM.

Several research gaps for future researches were proposed in literature, such as design of a simulation model that explains how the SC's performance metrics react to environmental and managerial control factors, perform sensitivity analysis, optimization, robustness analysis of the SC simulation model, application of the system is several organizations for providing more concrete results, and application of methods such as AHP, ANP and other mathematical tools in assessment.

It is important to highlight as limitations of this study the focus on aspects mentioned by the authors, because the qualitative approach is based on subjectivism, which may neglect many important aspects of the studies analyzed. Another limitation resides in the fact that the bibliographical researches have the possibility to present secondary data collected or processed in error, and thus spread or expand the errors (GIL, 2008). In order to minimize these limitations of the proposed research were analyzed only papers published in journals. Another point to stress is that the amount of analyzed papers and the number of content and approaches present in its structure, prevented deeper analysis of the results obtained in each production. Future papers may be developed, increasing the size of the sample analyzed, and deepening analyzes initiated here. 
DOI: 10.14807/ijmp.v5i4.238

Importantly, despite all the limitations inherent in the type of work proposed, the results contributed to characterize the profile of academic papers on the BSC with SCM. As conclusions of this paper can be stated that the use of the BSC as a performance measurement system for SCs chain encourages cooperation among members and creation of other assessment metrics and has a broader focus, with greater concern with SC effectively, addressing the need for joint efforts among its members for improving the performance of the whole chain.

\section{REFERENCES}

ADARME-JAIMES, W.; ARANGO-SERNA, M. D.; COGOLLO-FLÓREZ, J. M. (2012) Medición del desempeño para cadenas de abastecimiento en ambientes de imprecisión usando lógica difusa. Ing. Univ., v. 16, n. 1, p. 95-115.

AGAMI, N.; SALEH, M.; RASMY, M. (2012) A Hybrid Dynamic Framework for Supply Chain Performance Improvement. IEEE Systems Journal, v. 6, n. 3, p. 469-478.

AKYUZ, G. A.; ERKAN, T. E. (2010) Supply chain performance measurement: a literature review. International Journal of Production Research, v. 48, n. 17, p. 5137-5155.

ALFARO, J. J. et al. (2009) Business process interoperability and collaborative performance measurement. International Journal of Computer Integrated Manufacturing, v. 22, n. 9, p. 877-889.

BARBER, E. (2008) How to measure the "value" in value chains. International Journal of Physical Distribution \& Logistics Management, v. 38, n. 9, p. 685-698.

BARNABÈ, F. et al. (2013) The strategic micro-firm: a role play in management training for dynamic businesses. Journal of Workplace Learning, v. 25, n. 5, p. 328-342.

BERTO, R. M. V. S.; NAKANO, D. N. (2000) A produção científica nos anais do Encontro Nacional de Engenharia de Produção: um levantamento de métodos e tipos de pesquisa. Produção, v. 9, n. 2, p. 65-76.

BHAGWAT, R.; SHARMA, M. K. (2007a) Performance measurement of supply chain management: a balanced scorecard approach. Computers \& Industrial Engineering, v. 53, n. 1, p. 43-62.

BHAGWAT, R.; SHARMA, M. K. (2007b) Performance measurement of supply chain management using the analytical hierarchy process. Production Planning \& Control, v. 18, n. 8, p. 666-680.

BHAGWAT, R.; SHARMA, M. K. (2009) An application of the integrated AHP-PGP model for performance measurement of supply chain management. Production Planning \& Control, v. 20, n. 8, p. 678-690.

BHATTACHARYA, A. et al. (2014) Green supply chain performance measurement using fuzzy ANP-based balanced scorecard: a collaborative decision-making approach. Production Planning \& Control, v. 25, n. 8, p. 698-714. 
BIGLIARDI, B.; BOTTANI, E. (2010) Performance measurement in the food supply chain: a balanced scorecard approach. Facilities, v. 28, n. 5/6, p. 249-260.

BREWER, P. C.; SPEH, T. W. (2000) Using the balanced scorecard to measure supply chain performance. Journal of Business Logistics, v. 21, n. 1, p. 75-93.

BREWER, P. C.; SPEH, T. W. (2001) Adapting the balanced scorecard to supply chain management. Supply Chain Management Review, v. 5, n. 2, p. 48-56.

BULLINGER, H-J.; KÜHNER, M.; VAN HOOF, A. (2002) Analysing supply chain performance using a balanced measurement method. International Journal of Production Research, v. 40, n. 15, p. 3533-3543.

CARNEVALLI, J. A.; MIGUEL, P. A. C. (2008) Review, analysis and classification of the literature on QFD - types of research, difficulties and benefits. International Journal of Production Economics, v. 114, n. 2, p. 737-754.

CHANG, H. H. (2009) An empirical study of evaluating supply chain management integration using the balanced scorecard in Taiwan. The Service Industrial Journal, v. 29 , n. 2, p. $185-202$.

CHANG, H. H. et al. (2013) Using the balanced scorecard on supply chain integration performance - a case study of service businesses. Service Business, v. 7, n. 4, p. 539-561.

CHIA, A.; GOH, M.; HUM, S-H. (2009) Performance measurement in supply chain entities: balanced scorecard perspective. Benchmarking, v. 16, n. 5, p. 605-620.

CHILDERHOUSE, P.; TOWILL, D. R. (2011) A systems engineering approach to supply chain auditing. Journal of Manufacturing Technology Management, v. 22, n. 5, p. 621-640.

DE FELICE, F.; PETRILLO, A. (2013) Key success factors for organizational innovation in the fashion industry. International Journal of Engineering Business Management, v. 5, Especial Issue, p. 1-11.

FAN, X. et al. (2013) An evaluation model of supply chain performances using 5DBSC and LMBP neural network algorithm. Journal of Bionic Engineering, v. 10, n. 3, p. 383-395.

FORZA, C. (2002) Survey research in operations management: a process-based perspective. International Journal of Operations \& Production Management, v. 22, n. 2, p. 152-194.

FRANCESCHINI, F.; TURINA, E. (2012) Proposal for a performance dashboard for the monitoring of Water and Sewage Service Companies (WaSCs). Water

Resources Management, v. 26, n. 1, p. 63-80.

GIL, A. C. (2008) Métodos e técnicas de pesquisa social. 6. ed. São Paulo: Atlas. HOLIMCHAYACHOTIKUL, P. et al. (2014) Value creation through collaborative supply chain: holistic performance enhancement road map. Production Planning \& Control, v. 25, n. 11, p. 912-922.

KALL, E. et al. (2013) Análise da cadeia produtiva através do modelo de desempenho Balanced Scorecard. Espacios, v. 34, n. 4, p. 11-23.

KAPLAN, R. S.; NORTON, D. P. (1996) Using the balanced scorecard as a strategic management system. Harvard Business Review, Jan-Feb, p. 75-85. 
KHAJI, M. R.; SHAFAEI, R. (2011) A system dynamics approach for strategic partnering in supply networks. International Journal of Computer Integrated Manufacturing, v. 24, n. 2, p. 106-125.

KIM, J.; RHEE, J. (2012) An empirical study on the impact of critical success factors on the balanced scorecard performance in Korean green supply chain management enterprises. International Journal of Production Research, v. 50, n. 9, p. 24652483.

KLEIJNEN, J. P. C.; SMITS, M. T. (2003) Performance metrics in supply chain management. Journal of the Operational Research Society, v. 54, n. 5, p. 507514.

KNOTTS, T. L.; JONES, S. C.; UDELL, G. G. (2006) Using a "balanced approach" to measure merchandising supplier performance. Measuring Business Excellence, $v$. 10 , n. 1, p. 4-13.

KUENG, P.; WETTSTEIN, T.; LIST, B. (2001) A holistic process performance analysis through a performance data warehouse. In: AMERICAS CONFERENCE ON INFORMATION SYSTEM, 7, 2001, Boston. Proceedings... Boston, AIS Electronic Library, p. 349-356.

KUMAR, A.; OZDAMAR, L.; NG, C. P. (2005) Procurement performance measurement system in the health care industry. International Journal of Health Care Quality Assurance, v. 18, n. 2, p. 152-166.

LAKATOS, E. M.; MARCONI, M. A. (2007) Metodologia do trabalho científico: procedimentos básicos, pesquisa bibliográfica, projeto e relatório, publicações e trabalhos científicos. 7. ed. São Paulo: Atlas.

LI, S. et al. (2006) The impact of supply chain management practices on competitive advantage and organizational performance. Omega, v. 34, n. 2, p. 107-124.

LOHMAN, C.; FORTUIN, L.; WOUTERS, M. (2004) Designing a performance measurement system: A case study. European Journal of Operational Research, v. 156, n. 2 , p. $267-286$.

MIGUEL, P. A. C. (2007) Estudo de caso na engenharia de produção: estruturação e recomendações para sua condução. Produção, v. 17, n. 1, p. 216-229.

NAJMI, A.; MAKUI, A. (2012) A conceptual model for measuring supply chain's performance. Production Planning \& Control, v. 23, n. 9, p. 694-706.

NAINI, S. G. J.; ALIAHMADI, A. R.; JAFARI-ESKANDARI, M. (2011) Designing a mixed performance measurement system for environmental supply chain management using evolutionary game theory and balanced scorecard: A case study of an auto industry supply chain. Resources, Conservation and Recycling, v. 55, n. 6 , p. 593-603.

NGAI, E. W. T. et al. (2008) RFID research: an academic literature review (19952005) and future research directions. International Journal of Production

Economics, v. 112, n. 1, p. 510-520.

OLSMATS, C.; DOMINIC, C. (2003) Packaging scorecard - a packaging performance evaluation method. Packaging Technology and Science, v. 16, n. 1, p. 9-14. 
PARK, J. H.; LEE, J. K.; YOO, J. S. (2005) A framework for designing the balanced supply chain scorecard. European Journal of Information Systems, v. 14, n. 4, p. 335-346.

RAJESH, R. et al. (2012) Generic balanced scorecard framework for third party logistics service provider. International Journal of Production Economics, v. 140, n. 1, p. 269-282.

REEFKE, H.; TROCCHI, M. (2013) Balanced scorecard for sustainable supply chains: design and development guidelines. International Journal of Productivity and Performance Management, v. 62, n. 8, p. 805-826.

SHARMA, M. K.; BHAGWAT, R. (2007) An integrated BSC-AHP approach for supply chain management evaluation. Measuring Business Excellence, v. 11, n. 3, p. 5768.

SHAW, S.; GRANT, D. B.; MANGAN, J. (2010) Developing environmental supply chain performance measures. Benchmarking, v. 17, n. 3, p. 320-339.

SINGHAL, K.; SINGHAL, J. (2012) Opportunities for developing the science of operations and supply-chain management. Journal of Operations Management, v. 30, n. 3, p. 245-252.

THAKKAR, J.; KANDA, A.; DESHMUKH, S. G. (2009) Supply chain performance measurement framework for small and medium scale enterprises. Benchmarking, v. 16 , n. 5 , p. 702-723.

TSANG, A. H. C.; JARDINE, A. K. S.; KOLODNY, H. (1999) Measuring maintenance performance: a holistic approach. International Journal of Operations \& Production Management, v. 19, n. 7, p. 691-715.

VARMA, S.; WADHWA, S.; DESHMUKH, S. G. (2008) Evaluating petroleum supply chain performance: application of analytical hierarchy process to balanced scorecard. Asia Pacific Journal of Marketing and Logistics, v. 20, n. 3, p. 343-356.

VERDECHO, M. J.; ALFARO, J. J.; RODRIGUEZ-RODRIGUEZ, R. (2009) Foundations for collaborative performance measurement. Production Planning \& Control, v. 20, n. 3, p. 193-205.

VILLAS, M. V.; SOARES, T. D. L. V. A. M.; RUSSO, G. M. (2008) Bibliographical research method for business administration studies: a model based on scientific journal ranking. Brazilian Administration Review, v. 5, n. 2, p. 139-159.

WALTER, O. M. F. C.; TUBINO, D. F. (2013) Métodos de avaliação da implantação da manufatura enxuta: uma revisão da literatura e classificação. Gestão \& Produção, v. 20, n. 1, p. 23-45.

WANG, X.; LI, Z. (2011) An new evaluation model for synchronized supply chain based on entropy weight and TOPSIS. Advances in information Sciences and Service Sciences (AISS), v. 3, n. 10, p. 30-35.

WU, I-L.; CHANG, C-H. (2012) Using the balanced scorecard in assessing the performance of e-SCM diffusion: a multi-stage perspective. Decision Support Systems, v. 52, n. 2, p. 474-485.

XIAN, S.; QIU, D.; ZHANG, S. (2013) A fuzzy principal component analysis approach to hierarchical evaluation model for balanced supply chain scorecard grading. Journal of Optimization Theory and Applications, v. 159, n. 2, p. 518-535. 
DOI: 10.14807/ijmp.v5i4.238

YANG, J. (2009) Integrative performance evaluation for supply chain system based on logarithm triangular fuzzy number-AHP method. Kybernetes, v. 38, n. 10, p. 1760-1770.

ZIMMERMANN, K.; SEURING, S. (2009) Two case studies on developing, implementing and evaluating a balanced scorecard in distribution channel dyads.

International Journal of Logistics Research and Applications, v. 12, n. 1, p. 6381. 